\title{
Article \\ Changes in BNR Microbial Community in Response to Different Selection Pressure
}

\author{
Roya Pishgar ${ }^{1,2, *}$, John Albino Dominic ${ }^{1}$, Joo Hwa Tay ${ }^{1}$ and Angus Chu ${ }^{1}$ \\ 1 Department of Civil Engineering, University of Calgary, 2500 University Drive NW, Calgary, AB T2N 1N4, \\ Canada; johnalbino.dominic@ucalgary.ca (J.A.D.); jhatay@ucalgary.ca (J.H.T.); achu@ucalgary.ca (A.C.) \\ 2 Associated Engineering Alberta Ltd., 400-600 Crowfoot Cres NW, Calgary, AB T3G 0B4, Canada \\ * Correspondence: roya.pishgar@ucalgary.ca
}

check for updates

Citation: Pishgar, R.; Dominic, J.A.; Tay, J.H.; Chu, A. Changes in BNR Microbial Community in Response to Different Selection Pressure. Nitrogen 2021, 2, 474-490. https://doi.org/ $10.3390 /$ nitrogen 2040032

Academic Editors: Stephen Macko and Tida Ge

Received: 2 July 2021

Accepted: 29 November 2021

Published: 14 December 2021

Publisher's Note: MDPI stays neutral with regard to jurisdictional claims in published maps and institutional affiliations.

Copyright: (C) 2021 by the authors. Licensee MDPI, Basel, Switzerland. This article is an open access article distributed under the terms and conditions of the Creative Commons Attribution (CC BY) license (https:/ / creativecommons.org/licenses/by/ $4.0 /)$.

\begin{abstract}
This study investigated structural changes in microbial community of biological nutrient removal (BNR) in response to changes in substrate composition (ammonium and phosphate), redox condition, and morphological characteristics (flocs to granules), with a focus on nitrification and phosphate removal. Analyzing treatment performance and 16S rRNA phylogenetic gene sequencing data suggested that heterotrophic nitrification $(\mathrm{HN})$ and autotrophic nitrification (AN) potentially happened in aerobic organic-rich (HN_AS) and aerobic organic-deficient (AN_AS) activated sludge batch reactors, respectively. However, phosphate release and uptake were not observed under alternating anaerobic/aerobic regime. Phosphate release could not be induced even when anaerobic phase was extended, although Accumulibacter existed in the inoculum (5.1\% of total bacteria). Some potential HN (e.g., Thauera, Acinetobacter, Flavobacterium), AN (e.g., Nitrosomonas (3.2\%) and Nitrospira), and unconventional phosphate-accumulating organisms (PAOs) were identified. Putative HN bacteria (i.e., Thauera (29-36\%) and Flavobacterium (18-25\%)) were enriched in aerobic granular sludge (AGS) regardless of the granular reactor operation mode. Enrichment of HN organisms in the AGS was suspected to be mainly due to granulation, possibly due to the floc-forming ability of $\mathrm{HN}$ species. Thus, HN is likely to play a role in nitrogen removal in AGS reactors. This study is supposed to serve as a starting point for the investigation of the microbial communities of AS- and AGS-based BNR processes. It is recommended that the identified roles for the isolated bacteria are further investigated in future works.
\end{abstract}

Keywords: aerobic granule; activated sludge; biological nutrient removal (BNR); heterotrophic nitrification; polyphosphate accumulating organisms (PAOs)

\section{Introduction}

Molecular techniques have identified numerous bacteria from diverse genera and phyla, and sometimes organisms from distinct kingdoms (i.e., Archaea and Eukarya) in wastewater treatment processes [1,2]. Biological functions of most wastewater organisms have remained unexplored, with the attention focused on certain organisms that are believed to play fundamental functional roles in selected series of transformations such as autotrophic nitrification (AN), anoxic denitrification (AXD), and classical anaerobic phosphorus $(\mathrm{P})$ release/aerobic $\mathrm{P}$ uptake.

Recently, heterotrophic nitrification $(\mathrm{HN})$ has been attributed to diverse bacteria distributing across ten genera, including Arthrobacter [3], Acinetobacter [4,5], Pseudomonas [6,7], Alcaligenes [8], Bacillus [9,10], Thiosphaera [11], Comamonas [12], and Thauera [1]. In most of these studies, it is reported that the identified $\mathrm{HN}$ species can simultaneously perform $\mathrm{HN}$ and aerobic denitrification (AD). Integrating HN-AD process by a single species is of practical interest, because it can result in convenient simultaneous nitrification-denitrification (SND) in a single biological wastewater treatment reactor. The SND can be accomplished in a single bioreactor using emerging technologies such as anaerobic ammonium oxidation (anammox) and aerobic granular sludge (AGS), albeit with difficulty, because certain 
operating conditions should be maintained to allow culturing organisms with incompatible metabolic requirements, i.e., anammox, $\mathrm{AN}$, and $\mathrm{AXD}$ bacteria, and polyphosphateaccumulating organisms (PAOs) $[13,14]$.

The HN capacity and optimal growth conditions of HN bacteria have been mainly investigated in pure cultures so far $[3,10,15]$. Due to pure-culture biases, derived conclusions from these studies cannot be extrapolated to real-time conditions in wastewater treatment processes where mixed microbial consortia are present. This necessitates further research to shed light on the contribution of HN bacteria to wastewater treatment in biological nutrient removal (BNR) processes.

In addition, there are uncertainties about efficiency and microbiology of enhanced biological phosphate removal (EBPR), a BNR process developed based on classical anaerobic release-aerobic uptake of orthophosphate (ortho-P) [16]. Nonetheless, it has been suggested that the PAOs can maintain their metabolism under continuously aerobic condition as well $[17,18]$. Ortho-P removal mechanism under such circumstance is not well understood.

Through lab- and full-scale studies, Rhodocyclus-related bacteria, namely "Candidatus Accumulibacter phosphatis" (in short, Accumulibater), is recognized as major PAO species [19]. Yet, Acinetobacterial PAOs are found more abundantly in full-scale EBPR processes [20-22], implying the potential role of these organisms in EBPR. Moreover, the possible role of some other species in phosphate accumulation has recently been pointed out, such as Dechloromonas belonging to Betaproteobacteria, Acinetobacterial filament "Candidatus Microthrix parvicella" (hereinafter, Microthrix), Corynebacterium, Pseudomonas, and Acinetobacteria $[20,21,23]$. Accumulation of poly-P granules has been observed in the cellular tissues of some of these species [21,24]. These uncertainties and ambiguities warrant further research on EBPR microbiology coupled with its performance.

Therefore, this study attempted to investigate structural changes in functional populations of BNR microbial community in response to different selection pressures (i.e., substrate composition, redox condition, and physical transformation). Studying the effect of these changes on BNR microbial community is important to enable the operators and researchers to investigate and understand the link between process performance and operational changes. Raw wastewater shows fluctuations in substrate composition and loadings on daily and seasonal bases. For example, a Canadian domestic wastewater sample has shown large variations in biochemical oxygen demand (BOD), chemical oxygen demand (COD), and total suspended solids (TSS) throughout a year, in ranges of $80-1000 \mathrm{mg} / \mathrm{L}$, $100-1650 \mathrm{mg} / \mathrm{L}$, and 120-1330 mg/L TSS, respectively (author's personal experience). Variations in redox conditions are the essence of the design of AS-based BNR processes. Different redox conditions can happen in a single AGS granule. Physical transformation from suspended microbial cells to AS flocs has been constantly observed in AS basins, and it is the foundation of AGS processes. It has been hypothesized that BNR microbial community responds to these changes, which can therefore reflect in BNR process performance.

As such, the objectives of this study were to (i) determine evolution in activated sludge (AS) microbial structure under given incubation conditions deemed suitable for $\mathrm{HN}$, in order to identify putative HN species; (ii) demonstrate whether dissolved oxygen (DO) enrichment can sustain PAO population and EBPR performance of AS under DO-rich condition; and (iii) study EBPR microbiology and performance under anaerobic/aerobic operating regime. The scope of the study was defined to address a few gaps in knowledge identified in the literature as outlined above, including understanding the contribution of $\mathrm{HN}$ bacteria to total nitrogen (TN) removal in BNR processes, and microbiology and performance of biological P removal under different redox conditions (i.e., aerobic heterotrophic, aerobic autotrophic, heterotrophic anaerobic/aerobic, and heterotrophic extended anaerobic media). Four AS batch studies were performed with these media, and the information collected from these batch studies were extrapolated to AGS bioreactors, to identify functional species in AGS. 
It is hoped that this study can start a conversation about microbial communities of ASand AGS-based BNR processes under different circumstances and can, hence, help further practical knowledge pertaining to BNR processes and their optimization.

\section{Materials and Methods}

\subsection{Experimental Setups and Operational Conditions}

To perform AS experiments, geometrically-identical cylindrical bioreactors ABDOS ${ }^{\mathrm{TM}}$ P50607 Large Capacity PP Beakers, 5000 mL (Cole-Parmer, Montreal, QC, Canada) were used, with the specifications described in Pishgar et al. [25,26]. Briefly, the dimensions of these bioreactors included internal diameter (ID) of $18.7 \mathrm{~cm}$, height (H) of $20 \mathrm{~cm}$, and working volume (WV) of $5 \mathrm{~L}$.

Synthetic wastewater with given substrate compositions, which would stimulate the growth of microorganisms of interest, was prepared and added to the relevant bioreactor one time at the beginning of the operation (Table 1). The experiments were continued until observing a decay phase in the microbial growth pattern, to allow the completion of substrate conversions and the associated bioreactions. This would ensure that the expected changes in the microbial communities had occurred. In aerobic experiments, continuous aeration was provided using fine pore diffusers (Pentair AS40, Minneapolis, MN, USA), alongside mixing for homogenization. In anaerobic experiments, mechanical mixers (laboratory mixer Stir-Pak Model 04555-00 (Cole-Parmer, Montreal, QC, Canada), equipped with three-bladed propeller were used. DO concentration was monitored in situ intermittently (i.e., at the sampling times), to ensure achieving the target environmental conditions as delineated in Table 1 . The experiments were conducted in triplicate.

Table 1. Media composition.

\begin{tabular}{|c|c|c|c|c|c|c|}
\hline Bioreactor ID & HN_AS & AN_AS & AN/O_AS & ExAN_AS & AN/O/AX/O_SBR & O_SBR \\
\hline $\mathrm{COD}(\mathrm{mg} / \mathrm{L})$ & 5500 & - & 1000 & 1000 & 2000 & 2000 \\
\hline $\mathrm{HCO}_{3}(\mathrm{mg} / \mathrm{L})$ & - & 800 & - & - & 800 & 800 \\
\hline Peptone (mg/L) & 700 & - & - & - & - & - \\
\hline $\mathrm{NH}_{4}-\mathrm{N}^{\mathrm{a}}(\mathrm{mg} / \mathrm{L})$ & - & 100 & 55 & 55 & 100 & 100 \\
\hline $\mathrm{PO}_{4}-\mathrm{P}^{\mathrm{a}}(\mathrm{mg} / \mathrm{L})$ & 40 & 40 & 40 & 40 & 20 & 20 \\
\hline Trace element $(\mathrm{mL} / \mathrm{L})$ & 1 & 1 & 1 & 1 & 1 & 1 \\
\hline $\mathrm{MLSS}_{\text {in }}{ }^{\mathrm{a}}(\mathrm{mg} / \mathrm{L})$ & 700 & 700 & 700 & 700 & 2800 & 2800 \\
\hline
\end{tabular}

${ }^{a} \mathrm{NH}_{4}-\mathrm{N}$ were supplied using $\mathrm{NH}_{4} \mathrm{Cl}$. Phosphorus was supplemented in the form of phosphate buffer $\left(\mathrm{pH}=6.65\right.$ at $\left.25^{\circ} \mathrm{C}\right)$ composed of $\mathrm{KH}_{2} \mathrm{PO}_{4}$ and $\mathrm{K}_{2} \mathrm{HPO}_{4}$. MLSS in stands for initial biomass concentration.

To perform AGS experiments, the granules were cultivated and the treatment performance was investigated in two geometrically identical, bubble-column, granular sequencing batch reactors (GSBRs), with the specifications described in Pishgar et al. [27-29] and Pishgar [30]. Briefly, the AGS reactors' dimensions included ID of $13.7 \mathrm{~cm}, \mathrm{H}$ of $150 \mathrm{~cm}$, and WV of $18 \mathrm{~L}$. The GSBRs were operated under two different modes: (i) alternating anaerobic/aerobic/anoxic/aerobic mode (AN/O/AX/O_SBR bioreactor): 8 min fill, $55 \mathrm{~min}$ anaerobic (effluent recirculation for mixing), $104 \mathrm{~min}$ aeration, $1 \mathrm{~min}$ fill, $30 \mathrm{~min}$ anoxic (effluent recirculation for mixing), $30 \mathrm{~min}$ aeration, $10 \mathrm{~min}$ settle, and $2 \mathrm{~min}$ decant; (ii) purely aerobic mode (O_SBR bioreactor): $8 \mathrm{~min}$ fill, $220 \mathrm{~min}$ aeration, $10 \mathrm{~min}$ settle, 2 min decant. Cycle duration, volumetric exchange ratio, hydraulic retention time (HRT), and aeration intensities in the GSBRs were identical $(4 \mathrm{~h}, 60 \%$, and $6.7 \mathrm{~h}$, and $2.7 \mathrm{~cm} / \mathrm{s}$, respectively).

\subsection{Inoculum and Media}

The BNR return activated sludge (RAS) was collected from Pine Creek BNR WWTP, Calgary, AB, Canada, and used as seed for both AS and AGS experiments. The inoculum's mixed liquor suspended solids (MLSS) concentration was $7746 \pm 498 \mathrm{mg} / \mathrm{L}$ and had a volatile content of $81 \pm 1.2 \%$. Median floc size of the inoculum was $126 \pm 7 \mu \mathrm{m}$. The 
volumes of 10 and $30 \%(v / v)$ were inoculated into AS bioreactors and GSBRs, resulting in initial biomass concentrations (MLSS in $_{\text {) }}$ of 700 and $2800 \mathrm{mg}$ MLSS/L, respectively. Due to limited mixing capacity of AS bioreactors, relatively diluted initial mixed liquor concentration was chosen for AS experiments to avoid biomass settling at the farthest zones (from the mixer and/or diffuser) of the bioreactors. It would otherwise cause having less active or completely inactive biomass in local zones of the bioreactors, which could distort the results of microbial community analysis.

The compositions of the used media are summarized in Table 1. Experimental design and operating conditions and objective of each batch study are defined in Table 2. In AS experiments, medium compositions and metabolic conditions were adjusted to encourage proliferation of certain group of bacterial species in each bioreactor.

Table 2. Experiment design and operating conditions.

\begin{tabular}{|c|c|c|c|c|c|c|}
\hline Bioreactor ID & HN_AS & AN_AS & AN/O_AS & ExAN_AS & \multicolumn{2}{|c|}{ AN/O/AX/O_SBR } \\
\hline $\begin{array}{c}\text { Type of } \\
\text { experiment }\end{array}$ & \multicolumn{4}{|c|}{ Activated sludge (AS) } & \multicolumn{2}{|c|}{ Aerobic granular sludge (AGS) } \\
\hline Purpose & \multicolumn{4}{|c|}{$\begin{array}{l}\text { To determine functionally important nitrifying and phosphate accumulating } \\
\text { bacteria under given incubation conditions. }\end{array}$} & \multicolumn{2}{|c|}{$\begin{array}{l}\text { To demonstrate potential BNR pathway } \\
\text { under different incubation conditions, } \\
\text { with the consideration of functional } \\
\text { roles identified for the dominating } \\
\text { bacteria through the AS experiments. }\end{array}$} \\
\hline Objective & $\begin{array}{l}\text { Heterotrophic } \\
\text { nitrification }(\mathrm{HN})\end{array}$ & $\begin{array}{l}\text { Autotrophic } \\
\text { nitrification }(\mathrm{AN})\end{array}$ & $\begin{array}{l}\text { Biological } \\
\text { phosphate } \\
\text { removal }\end{array}$ & $\begin{array}{l}\text { Biological } \\
\text { phosphate } \\
\text { removal }\end{array}$ & $\begin{array}{l}\text { Granulation } \\
\text { under alternating } \\
\text { condition }\end{array}$ & $\begin{array}{l}\text { Granulation } \\
\text { under purely } \\
\text { aerobic condition }\end{array}$ \\
\hline Operation & Batch (onetime) & Batch (onetime) & Batch (onetime) & Batch (onetime) & $\begin{array}{c}\text { Batch } \\
\text { (sequencing) }\end{array}$ & $\begin{array}{c}\text { Batch } \\
\text { (sequencing) }\end{array}$ \\
\hline $\begin{array}{l}\text { Experimental } \\
\text { conditions }\end{array}$ & $\begin{array}{l}\text { Substrates: } \\
\text { Organic carbon }+ \\
\text { organic nitrogen } \\
\text { (peptone); aerobic }\end{array}$ & $\begin{array}{c}\text { Substrates: } \\
\text { inorganic carbon } \\
\text { + inorganic } \\
\text { nitrogen } \\
\text { (ammonium); } \\
\text { aerobic }\end{array}$ & $\begin{array}{l}\text { Alternating anaer- } \\
\text { obic/aerobic }\end{array}$ & $\begin{array}{l}\text { Anaerobic } \\
\text { (extended) }\end{array}$ & $\begin{array}{l}\text { Alternating } \\
\text { anaerobic- } \\
\text { aerobic-anoxic- } \\
\text { aerobic }\end{array}$ & Purely aerobic \\
\hline $\begin{array}{l}\text { Carbon }(\mathrm{COD}) \\
\quad \text { source }\end{array}$ & $\mathrm{NaAc}^{\mathrm{a}}(100 \%)$ & $\begin{array}{l}\text { Bicarbonate } \\
\quad(100 \%)\end{array}$ & $\mathrm{NaAc}^{\mathrm{a}}(100 \%)$ & $\mathrm{NaAc}^{\mathrm{a}}(100 \%)$ & $\begin{array}{l}\mathrm{NaAc}^{\mathrm{a}}(25 \%)+ \\
\operatorname{NaPr}^{\mathrm{a}}(75 \%)\end{array}$ & $\begin{array}{l}\mathrm{NaAc}^{\mathrm{a}}(25 \%)+ \\
\operatorname{NaPr}^{\mathrm{a}}(75 \%)\end{array}$ \\
\hline
\end{tabular}

${ }^{a}$ NaAc: Sodium acetate; NaPr: Sodium propionate.

In heterotrophic nitrification AS experiment (HN_AS bioreactor), the biomass was exposed to high concentrations of organic matter (5500 mg chemical oxygen demand (COD)/L) and organic nitrogen (100 mg total nitrogen (TN)/L, solely supplemented by peptone) to satisfy the growth requirement of heterotrophic nitrifiers. Carbon to nitrogen $(\mathrm{C} / \mathrm{N})$ ratio is reported as a critical factor for $\mathrm{HN}$. Optimum range of $\mathrm{C} / \mathrm{N}$ ratio (5-12) could promote growth and enrichment of $\mathrm{HN}$ bacteria $[5,7,9,10,31-33]$. As such, in HN_AS medium, initial concentrations of total organic carbon (TOC) and TN were adjusted to achieve $\mathrm{C} / \mathrm{N}$ ratio of 10 which, as suggested by van Niel et al. [34], could cause $\mathrm{HN}$ species to outcompete autotrophic ammonium oxidizers (e.g., Nitrosomonas europaea). Different sources of organic nitrogen can serve $\mathrm{HN}$ as sole nitrogen source. Examples of organic nitrogenous substrates for $\mathrm{HN}$ are oximes (e.g., pyruvic oxime and acetaldoxime), hydroxamic acids, amino acids (e.g., glycine, and L-glutamic acid), urea, maize straw, yeast extract, peptone, and casein [35-39]. In this study, peptone was selected.

In the autotrophic nitrification AS experiment (AN_AS bioreactor), ammonium was the sole nitrogen source and bicarbonate was added as inorganic carbon source required for the growth of autotrophic nitrifiers. The AH_AS experiment was supposed to serve as a negative control to justify the ecophysiological rationale used to identify potential heterotrophic nitrifiers.

To investigate $\mathrm{P}$ removal, the AS experiment was performed under alternating anaerobic/aerobic regime (AN/O_AS bioreactor). A purely anaerobic AS experiment for achieving an extended anaerobic period (ExAN_AS bioreactor) was conducted to ensure that anaerobic $P$ release would have enough time to emerge. Biological $P$ removal could also be 
monitored in organic-rich HN_AS and organic-deficient AN_AS media, because phosphate was added to HN_AS and AN_AS bioreactor as supplementary nutrient (see Table 1).

The AGS experiments were designed to investigate the microbial diversity of AGS developed under distinct incubation conditions. High COD concentration was adopted in these experiments (Table 1 ) to rapidly grow aerobic granules under high organic loading condition (i.e., $7 \mathrm{~kg} \mathrm{COD} / \mathrm{m}^{3} / \mathrm{d}$ ). The $\mathrm{N}$ and $\mathrm{P}$ were supplemented to support aerobic growth requirement of bacteria (i.e., COD:N:P = 100:5:1). Wastewater composition and substrate loading were fixed to impose certain selection pressure by nourishment condition on the AGS in the GSBRs. To read more about AGS development, maturation, and characteristics, as well as AGS treatment performance, refer to Pishgar et al. [27-29] and Pishgar [30].

\subsection{Water Quality and Microbial Community Analyses}

Water quality analyses included $\mathrm{pH}$ and temperature (YSI MultiLab IDS 4010-3). In situ DO concentration was carried out using portable probe (YSI ProComm II, Yellow Springs, OH, USA). MLSS concentration was determined based on the mean of four replicates, following standard methods [40]. MLSS measurement of AS reactors was performed using a calibration curve and optical density measurements at $620 \mathrm{~nm}\left(\mathrm{OD}_{620}\right)$, to avoid significant biomass loss and disruption in the process. Samples were centrifuged (6000 rpm for 10 min in Hermle Z 206 A, Wehingen, Germany) and filtered ( $0.45 \mu$ m Hydrophobic Teflon ${ }^{\circledR}$, SCP Science, Mississauga, ON, Canada) prior to the subsequent analyses. COD and $\mathrm{NH}_{4}-\mathrm{N}$ concentrations were measured in accordance with standard methods [40], using $\mathrm{Hach}^{\circledR}$ kits (Mississauga, $\mathrm{ON}$, Canada). Anions $\left(\mathrm{NO}_{3}{ }^{-}, \mathrm{NO}_{2}{ }^{-}, \mathrm{PO}_{4}{ }^{3-}\right.$ ) were analyzed using ion chromatography (Metrohm Enviro Pro IC, the column Metrosep A Supp 5-100/4.0, Mississauga, ON, Canada). A TOC/TN analyzer (Shimadzu TOC-LCPH and TNM-L with ASI-L autosampler, $720^{\circ} \mathrm{C}$ catalytic thermal decomposition/chemiluminescence method, West Chicago, IL, USA) was used for combined TOC and TN measurements.

In AS experiments, the data points were obtained using the mean of a total of six readings (two measurements from each of the three replicates). The AGS data were taken from a typical SBR cycle during maturation phases (day 59 in AN/O/AX/O_SBR and day 53 in O_SBR). Samples were withdrawn at proper time intervals to reflect the dynamics of substrate conversions.

Microbial community analysis was performed using 16S rRNA phylogenetic gene sequencing and constructing the corresponding clone library. This analysis is described in Pishgar et al. [26-29] and Pishgar [30] in detail. Briefly, genomic DNA of samples was extracted using DNeasy PowerSoil Kit from QIAGEN, Inc. (Calgary, AB, Canada). Pairedend sequencing was conducted (Illumina MiSeq platform, San Diego, CA, USA) using two primers ( $357 \mathrm{wF}$ and $785 \mathrm{R}$ ) to identify $16 \mathrm{~S}$ rRNA phylogenetic genes. The microbial analyses were performed at the Centre for Health Genomics and Informatics in the Cumming School of Medicine, University of Calgary, which deposits the data generated from MiSeq and runs on its own server and on Illumina's BaseSpace Sequence Hub. Sampling for the microbial analysis is described in Pishgar et al. [26] and Pishgar [30].

\section{Results and Discussion}

\subsection{Treatment Performance}

\subsubsection{Heterotrophic Nitrification}

HN_AS biomass showed different nitrogen removal abilities (Figure 1a). Initial TN concentration reduced to $12.8 \mathrm{mg} / \mathrm{L}$ within 43 , which corresponded to $87 \%$ removal efficiency. Accumulation of small concentrations of ammonium and nitrite were observed in $42-67 \mathrm{~h}$ which, respectively, declined to trace concentrations of 0.89 and $0.23 \mathrm{mg} \mathrm{N} / \mathrm{L}$ in $116 \mathrm{~h}$. Nitrate accumulation started at hour 24 and continued with a constant rate of $0.35 \mathrm{mg} \mathrm{NO} 3-\mathrm{N} / \mathrm{L} / \mathrm{h}$. 

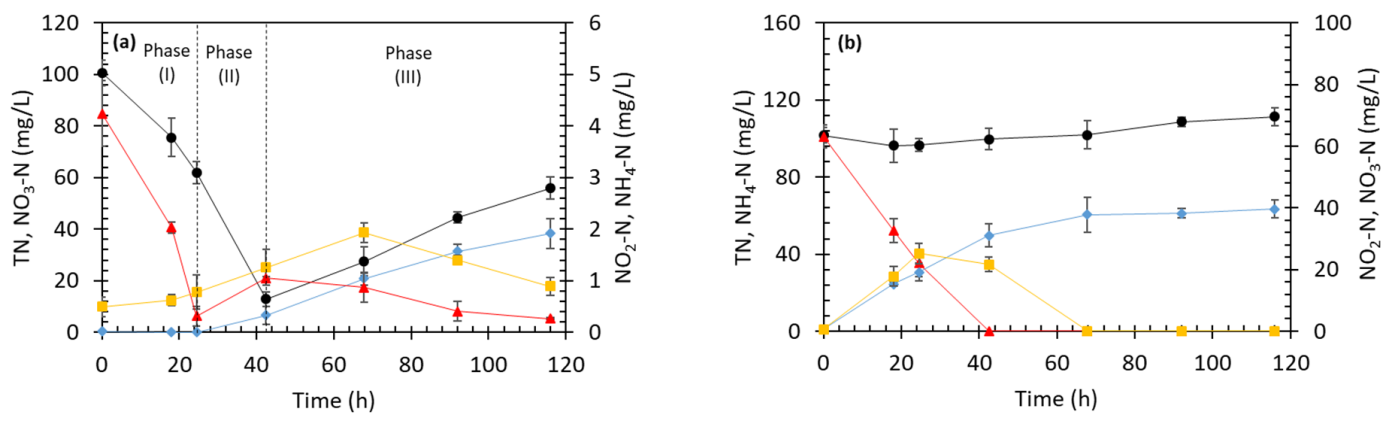

$\bullet-\mathrm{TN} \rightarrow \mathrm{NO3-N}-\mathrm{NO} 2-\mathrm{N} \rightarrow-\mathrm{NH} 4-\mathrm{N}$

Figure 1. Treatment performance of (a) heterotrophic nitrification (HN_AS) and (b) autotrophic nitrification activated sludge (AN_AS) bioreactors.

Accumulations of $\mathrm{NH}_{4}{ }^{+}, \mathrm{NO}_{2}{ }^{-}$, and, especially, $\mathrm{NO}_{3}{ }^{-}$suggested that $\mathrm{HN}$ might happen in this bioreactor. In organic $\mathrm{HN}$ pathway (also known as ammonification), organic nitrogen (general formula of $\mathrm{R}^{-\mathrm{NH}_{2}}$ ) is hydrolyzed to $\mathrm{NH}_{4}{ }^{+}$. In the consecutive inorganic $\mathrm{HN}$ steps, $\mathrm{NH}_{4}{ }^{+}$is converted to $\mathrm{NH}_{2} \mathrm{OH}, \mathrm{NO}_{2}{ }^{-}$, and then $\mathrm{NO}_{3}{ }^{-}$[4]. In direct oxidative pathway (another type of organic nitrification), $\mathrm{HN}$ bacteria directly oxidize organic nitrogen to the end products (i.e., $\mathrm{NH}_{2} \mathrm{OH}$ or $\mathrm{NO}_{3}{ }^{-}$), with minor or no intermediate metabolite production. Examples include Alcaligenes faecalis [8], Pseudomonas stutzeri [41], and Acinetobacter sp. [4]. Accumulation of trace concentrations of intermediate products, i.e., $\mathrm{NH}_{4}{ }^{+}$ and $\mathrm{NO}_{2}{ }^{-}$, could propose greater share of direct oxidative pathway to overall $\mathrm{N}$ removal.

Biological assimilation and $\mathrm{HN}$ could simultaneously contribute to $\mathrm{TN}$ removal during the first $24 \mathrm{~h}$ (phase I, Figure 1a). Organic HN could convert organic nitrogen to ammonium which could be taken up rapidly for growth. Conversion of any type of nitrogen to glutamate before incorporation into cell mass is a must. Ammonium is the precursor of glutamate and thus is the preferred source of nitrogen for assimilation. If available, it is primarily used for cell synthesis [31,42]. The exponential growth of biomass (Figure S1a) suggested that within the first $43 \mathrm{~h}$ when TN removal was under progress, biomass experienced a drastic growth and MLSS reached a maximal value of $1260 \mathrm{mg} / \mathrm{L}$ at $43 \mathrm{~h}$. During this time, TN treatment was accompanied by mineralization of organic matter (compare Figure 1a and Figure S1b); COD concentration of $5500 \mathrm{mg} / \mathrm{L}$ was degraded by $99 \%$ within the first $43 \mathrm{~h}$ of the operation, with an estimated degradation rate of $128 \mathrm{mg}$ $\mathrm{COD} / \mathrm{L} / \mathrm{h}$. Rapid biodegradation of high COD concentration caused rapid depletion of available oxygen, and thus, limited DO was observed during the first $24 \mathrm{~h}$ (Figure S1c), although air was constantly diffused into the bioreactor. When organic matter became scarce at $24 \mathrm{~h}$, biomass autolysis and decay commenced (Figure S1a), nitrate concentration increased, and TN profile showed an increasing trend instead of being further reduced (Figure 1a).

Co-occurrence of nitrogen assimilation and $\mathrm{HN}$ seems to be a common phenomenon. For instance, Alcaligenes faecalis could remove $38-50 \%$ of $500-1000 \mathrm{mg} \mathrm{NH}_{4}-\mathrm{N} / \mathrm{L}$, which was attributed to incorporation into cellular tissues [43]. According to Sun et al. [42], ammonium assimilation is a crucial accessory for AD which typically follows HN. Assimilation of ammonium affects $\mathrm{HN}$ positively through increasing the count of $\mathrm{HN}$ bacteria [42]. However, it seems that contribution of assimilation to overall nitrogen removal would increase if high $\mathrm{C} / \mathrm{N}$ ratio $(>10)$ is maintained. Thus, optimal $\mathrm{C} / \mathrm{N}$ ratio of $5-7$ has been anticipated for HN [33,42].

In Phase II, HN possibly became the principal nitrogen removal pathway when COD concentration became limited at $24 \mathrm{~h}$ and $\mathrm{C} / \mathrm{N}$ ratio reduced to 7 (Figure 1a). In this phase, the process was not accompanied by exponential biomass growth anymore. A stationary phase occurred from $24 \mathrm{~h}$ onward (Figure S1a), at which TN removal rate of $2.7 \mathrm{mg} \mathrm{TN} / \mathrm{L} / \mathrm{h}$ was estimated. 
Accumulation of $\mathrm{NO}_{3}{ }^{-}$in phase III (Figure 1a) could suggest that the activity of $\mathrm{HN}$ bacteria could continue during death phase (Figure S1a). Cell decay and decomposition could discharge intracellular nitrogen into the surrounding environment in the form of ammonium, which could be immediately oxidized to nitrate via HN.

\subsubsection{Autotrophic Nitrification}

As mentioned in the Section 2, AN_AS bioreactor could serve as a negative control to justify the rationale used to identify putative $\mathrm{HN}$ bacteria (see previous section). Ammonium concentration of $100 \mathrm{mg} \mathrm{NH}_{4}-\mathrm{N} / \mathrm{L}$ was completely removed in $43 \mathrm{~h}$ (Figure $1 \mathrm{~b}$ ), with a removal rate of $2.4 \mathrm{mg} \mathrm{NH}_{4}-\mathrm{N} / \mathrm{L} / \mathrm{h}$. Nitrite and nitrate accumulated concurrently. Nitrite reached maximum concentration of $25 \mathrm{mg} \mathrm{N} / \mathrm{L}$ within $24 \mathrm{~h}$ and subsequently reduced during the following $36 \mathrm{~h}$. Nitrite was not detected after $68 \mathrm{~h}$. Nitrate gradually accumulated from the start of the operation. Its production rate sustained a fast pace (1.14 $\mathrm{mg} \mathrm{NO} \mathrm{NO}_{3}-\mathrm{N} / \mathrm{L} / \mathrm{h}$ ) up to $43 \mathrm{~h}$, whereas it significantly slowed down during the rest of the operation, leading to a plateau from $68 \mathrm{~h}$ onward.

TN concentration gradually increased slightly toward the end of the operation, which could be due to the combined effect of ammonium transformation to other nitrogen forms and cell decay. Under aerobic condition, initial ammonium concentration (i.e., $100 \mathrm{mg}$ $\mathrm{NH}_{4}-\mathrm{N} / \mathrm{L}$ ) was converted to nitrite, and then nitrate, as described above. In addition, according to cell decay stoichiometry shown in Equation (1), decrease in biomass concentration (Figure S1d), interpreted as biomass decay, could contribute to increase in ammonia concentration:

$$
\mathrm{C}_{5} \mathrm{H}_{7} \mathrm{NO}_{2}+5 \mathrm{O}_{2} \rightarrow 5 \mathrm{CO}_{2}+\mathrm{NH}_{3}+2 \mathrm{H}_{2} \mathrm{O}
$$

Anoxic denitrification could not proceed due to aerobic redox condition, hence the constant nitrate nitrogen concentration in the medium toward the end of operation. Consecutive AN steps were identical to those of inorganic $\mathrm{HN}$ pathways. It is because inorganic nitrogen sources (i.e., $\mathrm{NH}_{4}{ }^{+}, \mathrm{NO}_{2}{ }^{-}$, and $\mathrm{NO}_{3}{ }^{-}$) serve as substrates for both $\mathrm{AN}$ and $\mathrm{HN}[4,41]$. Thus, $\mathrm{HN}$ was likely to mutually contribute to ammonium removal in AN_AS medium. However, the trend of biomass concentration suggested that the role of $\mathrm{HN}$, if any, was insignificant. In the AN_AS bioreactor, MLSS continuously reduced from the beginning of operation, possibly due to lack of readily biodegradable organic matter for growth (Figure S1d). Constant biomass loss could testify that the consumption of removed ammonium was mainly for energy conservation, confirming the occurrence of catabolic AN reactions. Unlike AN, ammonium conversion via $\mathrm{HN}$ is not linked to energy generation [44]. Contrasting microbial community structure of AN_AS and HN_AS (see Section 3.2) could support this argument.

\subsubsection{Biological Phosphate Removal}

The AS biomass was subjected to shifting anaerobic/aerobic condition by switching aerator on-off (see DO concentration profile in Figure S2c). This oxygenation strategy was adopted to subject the microbial community to different redox conditions to investigate the AS biological phosphate removal capacity in the AN/O_AS bioreactor. Since a single $\mathrm{PAO}$ should experience anaerobic and aerobic conditions in sequence, such oxygenation pattern was defined to trigger biological phosphate removal by PAOs if they existed in the microbial culture. Between 1.3-2.3 h, the P profile showed an increasing trend (Figure 1a). However, the P release was not considerable and could not increase the initial P concentration of $38 \mathrm{mg} / \mathrm{L}$ more than $3 \%$. Minor anaerobic release could be due to significantly low population of Accumulibacter in the inoculum (5.1\%, see Section 3.2 and Figure S3a), compared to its population in robust EBPR processes (e.g., $20-60 \%$ of total bacteria [17,45]). During the rest of the anaerobic phase, reduction in P concentration happened, which is not characteristic of EBPR biomass [46]. During the subsequent aerobic phase (hours 4 to 5), the $P$ concentration remained almost constant.

In a second attempt, sparging air into the bioreactor was stopped from hour 9 to 48 (Figure 2a), to possibly encourage the activation of PAOs under an extended anaerobic 
phase. Yet, the biomass constantly showed P uptake activity. Upon resuming aeration at hour 48, rapid reduction in P started which lasted up to $72 \mathrm{~h}$, during which COD mineralization was under progress as well (Figure S2b). Upon complete depletion of biodegradable organic matter, the $\mathrm{P}$ removal pace slowed down afterward, which suggested that the $P$ removal was potentially linked to bacterial assimilation in the AN/O_AS bioreactor. Biomass growth occurred during the second anaerobic phase (from 24 to $48 \mathrm{~h}$ ) and the following aerobic phase, until COD was depleted (Figure S2a).
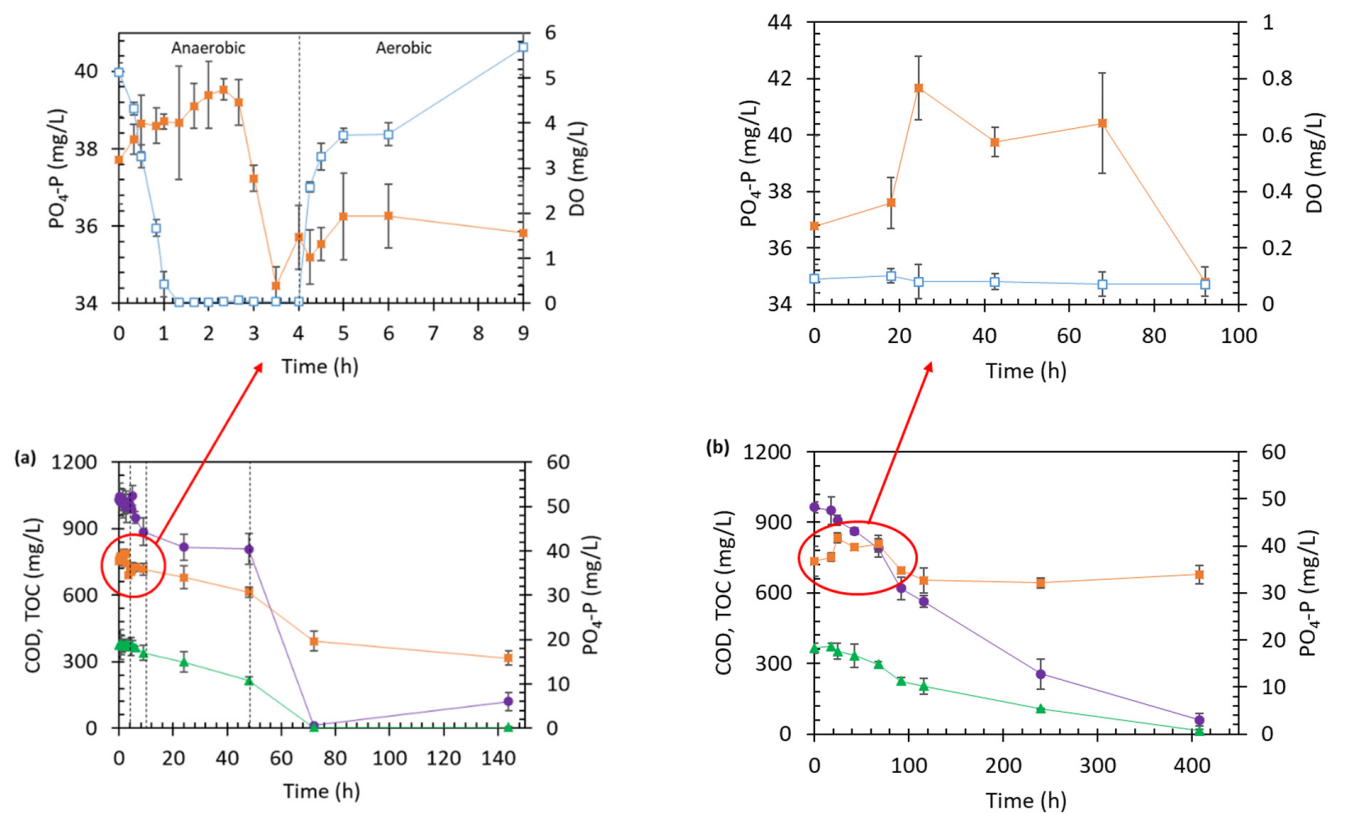

$-\mathrm{COD} \triangle \mathrm{TOC} \rightarrow-\mathrm{PO} 4-\mathrm{P}-\square-\mathrm{DO}$

Figure 2. Treatment performance of (a) alternating anaerobic/aerobic (AN/O_AS) and (b) extended anaerobic activated sludge (ExAN_AS) bioreactors.

The AS experiment was repeated under an extended anaerobic condition (i.e., ExAN_AS bioreactor) to provide further evidence regarding $P$ removal. Figure $2 b$ illustrates the changes in $\mathrm{P}$ and organic matter concentrations. A slight P release was observed initially; $\mathrm{P}$ concentration rose from 36.8 to $41.7 \mathrm{mg} / \mathrm{L}$ in $24 \mathrm{~h}$, which corresponded to a $13.3 \%$ increase. However, P release did not continue during the rest of the operation. Once again, such an increase was not comparable to anaerobic P release capacity of biomass with high PAO population and tangible EBPR capacity $[17,46]$. Reduction in P concentration coincided with $\mathrm{COD}$ and $\mathrm{NH}_{4}-\mathrm{N}$ removal, implying a relation between $\mathrm{P}$ removal and biomass growth in this reactor as well. Biomass concentration gradually increased up to hour 116 (Figure S2d). Degradation of about half (42\%) of COD concentration and partial removal $(32 \%)$ of $\mathrm{NH}_{4}-\mathrm{N}$ concentration coincided with biomass growth during the first $116 \mathrm{~h}$. Removal of ammonium and P stopped when biomass growth ceased at $116 \mathrm{~h}$. Thus, the $\mathrm{P}$ removal in the ExAN_AS reactor could be attributed to biomass assimilation.

Overall, an ultimate $P$ removal efficiency of $11 \%$ was achieved in the ExAN_AS bioreactor, while in the AN/O_AS bioreactor, initial P concentration of $37.7 \mathrm{mg} / \mathrm{L}$ was reduced to $15.8 \mathrm{mg} / \mathrm{L}$, with a removal efficiency of $58 \%$. Under aerobic conditions (i.e., HN_AS and AN_AS bioreactors where P was provided as a supplementary nutrient for nitrification), the AS could remove $27 \mathrm{mg}$ P/L at high organic loading in HN_AS and $10 \mathrm{mg}$ P/L in the COD-deficient environment of AN_AS, corresponding to 70 and 30\% removal efficiencies, respectively. Consumption of $10 \mathrm{mg}$ P/L in AN_AS, considering the organic-deficient environment of this reactor alongside no biomass growth (see Figure S1d), could reject the possibility that $P$ removal was solely due to biomass growth in either all of these bioreactors or, at least, only in AN_AS. 


\subsubsection{Aerobic Granular Sludge Performance}

AGS performance is discussed elsewhere [26,30]. Briefly, in a single cycle of the GSBR bioreactors, similar nitrogen removal performances were observed despite distinct operation modes. The $\mathrm{NO}_{x}{ }^{-}$(i.e., $\mathrm{NO}_{3}{ }^{-}+\mathrm{NO}_{2}{ }^{-}$) did not accumulate entirely, and thus the profiles of $\mathrm{TN}$ and $\mathrm{NH}_{4}-\mathrm{N}$ were intertwined. Identical $\mathrm{TN}$ and $\mathrm{NH}_{4}-\mathrm{N}$ removal efficiencies were therefore achieved (61 and 67\% in AN/O/AX/O_SBR and 48 and 49\% in O_SBR, respectively). P release/uptake did not happen in the GSBRs. Continuous P reduction occurred during the entire cycle, even during the anaerobic phase of AN/O/AX/O_SBR, a behavior which was shown by the AS experiments (see the previous section). The P decrease followed the same trend as those of COD and ammonium profiles, suggesting a connection between $P$ removal and heterotrophic activity in the GSBRs. COD and P removal efficiencies were 99 and 60 in AN/O/AX/O_SBR and 97 and 41\% in O_SBR, respectively.

\subsection{Changes in Microbial Community Structure and Population}

Phylogenetic analysis showed substantial structural changes in microbial communities under different selection pressures applied in this study (Figure 3). The readers are recommended to refer to the pie charts presented in Supplementary Materials for convenient chart reading and data extraction. The results are summarized in Table 3, where putative $\mathrm{HN}, \mathrm{AN}$, and PAOs are identified and important observations and supporting evidence are highlighted. Drawing from HN_AS and AN_AS results, dominant nitrifying organisms were identified in the AGS. However, this approach is speculative and requires further study on BNR processes to gather comprehensive, large databases which can allow establishing a solid relation between process performance and microbial structure.
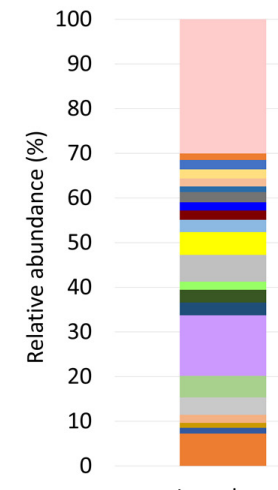

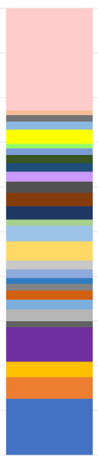

HN_AS

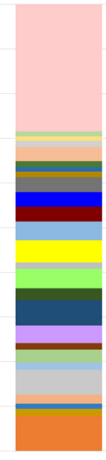

AN_AS

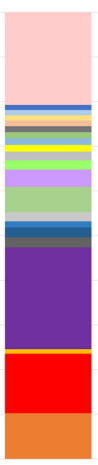

EXAN_AS

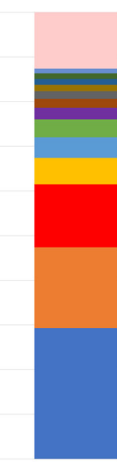

AN/O/AX/O_SBR

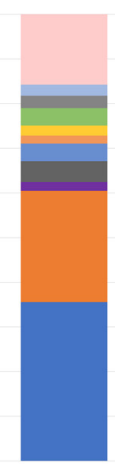

O_SBR

\footnotetext{
Others (genus $<1 \%$ ) Aciditalea, Rhodocyclaceae, Gammaproteobacteria, Proteobacteria Acidaminobacter, Family_XII, Clostridia, Firmicutes SM1A02, Phycisphaeraceae, Phycisphaerae, Planctomycetes - Pedobacter, Sh Shingobacteriaceae, Bacteroidia, Bacteroidetes
- Ideonella, Burkholderiaceae, Gammaproteobacteria, Proteobacteria - Teonella, Burkholderiaceae, Gammaproteobacteria, Proteo
- Terrimonas, Chitinophagaceae, Bacteroidia, Bacteroidetes - Nitrospira, Nitrospiraceae, Nitrospira, Nitrospirae Haliangium, Haliangiaceae, Deltaproteobacteria, Proteobacteria - Candidatus_Ovatusbacter, Unknown_Family, Gammaproteobacteria, Proteobacteria - Dokdonella, Rhodanobacteraceae, Gammaproteobacteria, Proteobacteria - Empedobacter, Weeksellaceae, Bacteroidia, Bacteroidetes - Aeromonas, Aeromonadaceae, Gammaproteobacteria, Proteobacteria Sediminibacterium, Chitinophagaceae, Bacteroidia, Bacteroidetes Prosthecobacter, Verrucomicrobiacea, Verrucomicrobiae, Verrucomicrobia - Brevundimonas, Caulobacteraceae, Alphaproteobacteria, Proteobacteria - Leadbetterella, Spirosomaceae, Bacteroidia, Bacteroidetes - Sphaerotilus, Burkholderiaceae, Gammaproteobacteria, Proteobacteria - Pseudomonas, Pseudomonadaceae, Gammaproteobacteria, Proteobacteria - Paracoccus, Rhodobacteraceae, Alphaproteobacteria, Proteobacteria - Bacteriovorax, Bacteriovoracaceae, Deltaproteobacteria, Proteobacteria - Paludibacter, Paludibacteraceae, Bacteroidia, Bacteroidetes Hydrogenophaga, Burkholderiaceae, Gammaproteobacteria, Proteobacteria - Acinetobacter, Moraxellaceae, Gammaproteobacteria, Proteobacteria - Arcoeabact Arco - Thauera, Rhodocyclaceae, Gammaproteobacteria, Proteobacteria
}

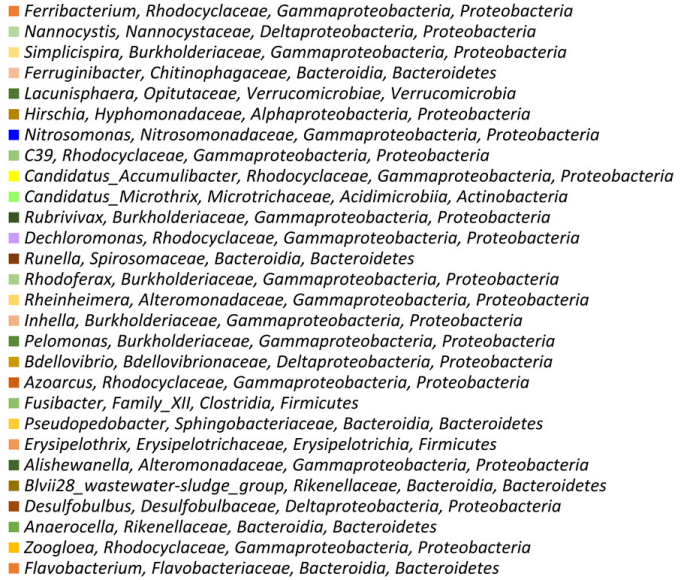

Figure 3. Microbial selection and population dynamics at genus-level inoculum, heterotrophic nitrification (HN_AS), autotrophic nitrification (AN_AS), extended anaerobic activated sludge (ExAN_AS) bioreactors, as well as granular biomass bioreactors (i.e., AN/O/AX/O_SBR and O_SBR). The legend shows genus, family, and phylum. 
Table 3. Dominant bacterial species under different selection pressures.

Biomass

Detected Species

Thauera, Acinetobacter, Flavobacterium, and Rheinheimera (4-13\%).

II. Pseudomonas, Paracoccus, and Zoogloea (2-3.5\%).

III. Sediminibacterium, Ca. Accumulibacter, Runella,

Aeromonas, Empedobacter, Dechloromonas,

Prosthecobacter, Dokdonella, Rubrivivax, unidentified

OLB12, Terrimonas, Rhodoferax, Hydrogenophaga, and

Ca. Microthrix (from $<2 \%$ to $3.5 \%$ ).

- $\quad$ AN species: Nitrosomonas (3.2\%) and Nitrospira (3.4\%).

- Dominant species: Dokdonella, Flavobacterium

Prosthecobacter, and Ca. Accumulibacter, Ca. Microthrix, unidentified OLB12, and Dechloromonas (4-8\%).

\section{Important Observations and the Supporting Evidence}

- $\quad$ Flavobacterium was the only species among them that could be detected in the inoculum (7\%)

- $\quad$ Evidence of HN-AD of Group I:

HN ability of Thauera could be speculated from [47] and its enzymatic suite suggested its ability to perform AD [1]

Acinetobacter could remove ammonium in a broad concentration range (5-500 $\mathrm{mg} / \mathrm{L} \mathrm{N}$ ) via HD, and nitrification and

denitrification intermediate metabolites (i.e., hydroxylamine, nitrite, and nitrate) as sole nitrogen sources $[4,5]$.

- Flavobacterium has been identified as anoxic denitrifier with heterotrophic nitrifying capability of hydroxylamine [35] No evidence of HN ability of Rheinheimera in the literature.

- The HD-AD ability of the Group II was speculated from [31,41], [32,48], and [49,50], respectively.

- $\quad$ Regarding Group III, there is no report in the literature about their HN capability.

- $\quad$ AN species enriched, although they were not dominant.

- Considering population structure and performance of the AN_AS bioreactor, it was supposed that these autotrophic species might perform well even at moderate populations.

Nitrosomonas and Nitrospira are the most dominant proteobacterial nitrifiers globally found in full-scale nitrifying reactors [51,52].

- Relative abundances of the dominant species were generally close to those observed in the inoculum and significantly higher than those seen in HN_AS bioreactor (4-8\%):

- The reason for detecting common bacteria in HN_AS and AN_AS biomass should be further investigated.

Autotrophic and heterotrophic ammonia monooxygenase enzymes show structural [44] and functional [53]

dissimilarities that can be used as biomarkers for differentiating $\mathrm{AN}$ and $\mathrm{HN}$ pathways.

- Acinetobacter favored anaerobic condition and was significantly enriched, as opposed to its population in the inoculum $(0.34 \%)$ and the aerobic environments ( $7.7 \%$ and $0.14 \%$ in HN_AS and AN_AS biomass, respectively):

$0 \quad$ This species was first identified as primary PAO in full-scale EBPR wastewater treatment plants. Later, culture-independent studies invalidated the role of Acinetobacter in EBPR performance and estimated that its population in EBPR processes was less than $10 \%$ of total bacteria [16,19].

- Acinetobacter $(23 \%)$

Dechloromonas $(3.9 \%)$

- Microthirx (2.1\%).

- Psuedomonas (0.2\%).

Recent studies have brought Acinetobacter back to the spotlight in this regard [24,54].

Using toluidine blue staining technique and scanning transmission electron microscopy, intracellularly stored poly-P granules were seen in Acinetobacter cells [21,24].

granules were seen in Acinetobacter cells [21,24]. The fact that Acinetobacter has emerged in EBPR

species in EBPR process was nullified hastily. However, the lack of anaerobic PAO phenotype (i.e., P release under anaerobic condition) and low overall P removal
efficiency (i.e., 11\%) of ExAN_AS bioreactor could indicate either of the following was correct: (a) an environmental factor hindered the EBPR activity; (b) Acinetobacter-derived phosphate removal from an unorthodox metabolic pathway; or (c) the former conclusion about the lack of EBPR capability of Acinetobacter. 
Table 3. Cont.

Biomass

- Acinetobacter $(23 \%)$

ExAN_AS

- Dechloromonas $(3.9 \%)$

- $\quad$ Psuedomonas $(0.2 \%)$

\section{Important Observations and the Supporting Evidence}

- Dechloromonas population decreased compared to its population in seed (13.5\%):

- Although Dechloromonas has been widely detected in EBPR processes, sometimes with considerably high

proportions [55-57], poly-P accumulating capability of this organism is still open to debate.

Kong et al. [55] retrieved 16S rRNA gene sequences of a Dechloromonas-related group from full-scale EBPR plant and Kong et al. [55] retrieved $16 \mathrm{~S}$ rRNA gene sequences

thus assigned poly-P accumulating phenotype to it. Using FISH technique coupled with intracellular poly-P staining, Ahn et al. [58] could not see poly-P
ability for this species, although the organism could assimilate acetate and store intracellular PHA.

Dechloromonas seems to be a denitrifying organism, with capability to reduce nitrate to nitrite [56]. Hence, the presence of Dechloromonas in EBPR processes might not be due to phosphate accumulation capacity of this species per se, but to form a syntrophic relation with Accumulibacter for enhancing denitrifying poly-P accumulation. Accumulibacter can couple poly-P accumulation with denitrification via nitrite [56,59-61].

- Population of Microthirx, belonging to the Actinobacteria phylum, remained similar to that of the inoculum (1.8\%), although it increased to $4.4 \%$ in the AN_AS bioreactor, indicating that it potentially preferred aerobic, organic-deficient environments of AN_AS:

A certain strain of Actinobacteria-related Microthrix (i.e., Ca. Microthirx parvicella) is identified as the common cause of sludge bulking in a number of full-scale EBPR [62,63], which is suspected to sustain phosphate removal capacity during sludge bulking incidents [62]

Actinobacteria-related PAOs significantly outnumbered Rhodocyclus-related PAOs in many full-scale EBPR facilities,

especially in industrial plants [22]

DNA annotation of $M$. parvicella has demonstrated that the strain has the genome inventory to use poly-P as energy

source for anaerobic uptake and storage of lipids [63]. Neisser staining found poly-P granules in this strain [62].

Thus, Microthirx has been suspected with poly-P accumulating phenotype [62,63].

However, EBPR mechanism and ability of this species has yet to be demonstrated.

- Psuedomonas population increased compared to seed (0.07\%) but decreased compared to HN_AS (2.2\%). It was 0.4\% in AN_AS, suggesting the inhibition effect of organic- and oxygen-deficient conditions on this species:

○ Poly-P granules were observed in Pseudomonas cells using electron microscopy [21]

Different Pseudomonas species (P. aeruginosa, P. putida, and P. fluorescens) are known to use poly-P to satisfy their

metabolic requirements. This capability was also observed for mutant strains of $P$. aeruginosa which lack polyphosphate kinase gene $(p p k)$. However, these species are not considered as true PAOs, mostly because their pathogenic activity (especially P. aeruginosa) has rendered research about them difficult $[64,65]$.

- Acinetobacter and Pseudomonas are supposed to have biocalcifying abilities (i.e., biocalcification in the form of calcite, aragonite, and/or vaterite). It is proposed that these species potentially contribute to $\mathrm{P}$ removal via $\mathrm{Ca}-\mathrm{P}$ crystallization on calcite surfaces, which could categorize P removal as the secondary effect of microbiologically-induced calcium carbonate precipitation (MICP) (see Pishgar et al. [28] and the references therein). 
Table 3. Cont.

Biomass

- Dominant genera: Thauera and Flavobacterium (29 and $18 \%$ in AN/O/AX/O_SBR and 36 and $25 \%$ in O_SBR respectively).

AGS

- Other putative HN species: Acinetobacter (2.6 and 2.0\%), Zoogloea (6.0 and 0.56\%), Chryseobacterium (4.6 and $0.36 \%)$, Paracoccus $(0.83$ and $0.97 \%)$, Pseudomonas (0.55 and $0.12 \%$, respectively).
Important Observations and the Supporting Evidence

- These organisms were isolated from the HN_AS biomass as well, except Chryseobacterium, whose HN capability is demonstrated by Kundu et al. [66].

- $\quad$ AN species (i.e., Nitrosomonas and Nitrospira) disappeared from AGS in both GSBRs, similar to their population profiles in HN_AS biomass.

- Identifying several HN bacteria suggested that ammonium removal was likely directed via HN in the GSBRs. Potentially, that was why no $\mathrm{NO}_{\mathrm{x}}{ }^{-}$buildup was observed in the GSBRs (refer to Pishgar et al. [26] and Pishgar [30] to read about the performance of GSBRs). Nitrogen species profiles in the HN_AS reactor (see the previous section) suggested that trace performance of GSBRs). Nitrogen species profiles in the
concentrations of $\mathrm{NO}_{x}{ }^{-}$could be produced, which would be eliminated very quickly. It agreed with the literature where $\mathrm{HN}$ species are reported to produce trace or no $\mathrm{NO}_{x}{ }^{-}$concentrations $[1,4,6,11,33,67]$, and that in the case of $\mathrm{NO}_{x}{ }^{-}$production, removal rates would be fast $[7,33]$

- Lower population of HN species in O_SBR potentially caused relatively low TN removal efficiency in the system (refer to Pishgar et al. [26] and Pishgar [30] to read about the performance of GSBRs).

- HN bacteria, such as Thauera, Flavobacterium, Acinetobacter, and Chryseobacterium, are recognized as floc formers, and enrichment of these species is widespread, reported in AGS. These species facilitate microbial aggregation through secreting

exopolysaccharide within which microorganisms are entrapped, and thus agrlomerate [1,68-70]. Hence, it is not unlikely that HN generally plays a role in nitrogen removal in granular reactors as hypothesized in Pishgar et al. [26] and Pishgar [30]. 


\section{Conclusions and Directions for Future Research}

The HN and AN potentially occurred in aerobic organic-rich (HN_AS) and organicdeficient (AN_AS) environments, respectively. This speculation was supported by treatment performance, enrichment of certain functional bacterial groups, and microbial growth patterns of these bioreactors.

Thauera, Acinetobacter, Flavobacterium, and Rheinheimera (4-13\%) were identified as potential HN bacteria, and Nitrosomonas (3.2\%) and Nitrospira (3.4\%) as potential AN bacteria. Some unconventional PAOs were isolated from ExAN_AS biomass, such as Acinetobacter (23\%), Dechloromonas (3.9\%), Microthirx (2.1\%), and Psuedomonas (0.2\%), whose $\mathrm{PAO}$ abilities are still open to debate. Conventional PAO Accumulibacter did not enrich in any of the bioreactors in this study.

The HN_AS biomass could simultaneously remove high COD (99\%) and organic nitrogen $(87 \%)$ concentrations within $43 \mathrm{~h}$. As such, it was suspected that bacterial assimilation was a co-contributor to nitrogen removal in $\mathrm{HN}$ reactions, and that $\mathrm{HN}$ became the principal nitrogen removal pathway $(2.7 \mathrm{mg} \mathrm{TN} / \mathrm{L} / \mathrm{h})$ when COD concentration became relatively scarce $(\mathrm{C} / \mathrm{N}=7)$.

Putative HN bacteria (i.e., Thauera (29-36\%) and Flavobacterium (18-25\%)) were enriched in AGS regardless of the granular reactor operation mode. Enrichment of HN organisms in the AGS was suspected to be mainly due to granulation, possibly because of the floc-forming ability of $\mathrm{HN}$ species.

This study should be seen as a starting point for the investigation of microbial structure of AS- and AGS-based BNR processes, and thus, the roles attributed to the isolated species warrant further research through systematic experimentation (e.g., factorial experiment design, multivariate statistical analysis, and total Kjeldahl nitrogen (TKN) testing).

Data collected using metagenomic analyses adopted in this study (16S rRNA phylogenetic gene sequencing) should be complemented with functional analysis using metaproteomic studies, especially focusing on functional genes responsible for BNR, to provide greater insight and add depth to the conclusions of this study. The scope of this study was mainly focused on short-term batch assays to investigate changes in microbial structure, using seed microbial culture as a benchmark, in response to the imposed operating conditions. Monitoring bacterial community in long-term experiments can be considered in future investigations to add the factor of time as an additional independent variable and to observe temporal variations in the microbial composition (i.e., structure and populations). Monitoring temporal changes in microbial composition of BNR processes can provide grounding for further statistical analysis, where the main and combined effects of time and operating conditions on microbial composition can be established.

In this study, changes in microbial communities under different conditions were based on single analysis of $16 \mathrm{~S}$ rRNA gene. Functional gene analysis alongside long-term experiments can help in collecting a larger database, which can help in verifying the conclusions of this study.

Moreover, incorporating TKN testing in the sampling and analysis regiment can provide additional insight about transformation of organic nitrogen to inorganic nitrogen species. TKN analysis in combination with functional gene analyses can provide solid evidence regarding heterotrophic nitrification.

Supplementary Materials: The following are available online at https://www.mdpi.com/article/10 $.3390 /$ nitrogen 2040032 /s1. Figure S1. Concentration profiles of soluble constituents, biomass, and environmental factors in $(\mathrm{a}-\mathrm{c})$ heterotrophic nitrification $(\mathrm{HN})$ and $(\mathrm{d}-\mathrm{f})$ autotrophic nitrification (AN) suspended-biomass batch bioreactors; Figure S2. Concentration profiles of soluble constituents, biomass, and environmental factors in $(\mathrm{a}-\mathrm{c})$ alternating anaerobic/aerobic (BioP_AN/O) and (d-f) extended biomass (BioP_ExAN) suspended-biomass batch bioreactors; Figure S3. Bacterial assembly of (a) inoculum; (b) heterotrophic nitrification (HN) AS biomass; (c) autotrophic nitrification (AN) AS biomass; (d) extended anaerobic (BioP_ExAN) AS biomass; (e) alternating (AN/O/AX/O_SBR) granular (AGS) biomass; and (f) purely aerobic (O_SBR) granular (AGS) biomass at genus level (relative abundances $1 \%$ ). 
Author Contributions: R.P.: conceptualization, data curation, investigation, methodology, visualization, writing —original draft, writing—review and editing; J.A.D.: conceptualization, investigation, validation, writing - review and editing; J.H.T.: funding acquisition, supervision; A.C.: supervision. All authors have read and agreed to the published version of the manuscript.

Funding: This research was funded by Natural Sciences and Engineering Research Council of Canada (NSERC, grant \# 10011088).

Institutional Review Board Statement: Not applicable.

Informed Consent Statement: Not applicable.

Data Availability Statement: The data presented in this study are mainly available in this article and its Supplementary Materials. Additional information and data can be found in Pishgar et al. [25-29] and Pishgar [30].

Acknowledgments: This study was funded by Natural Sciences and Engineering Research Council of Canada (NSERC) and the revision process was supported by Associated Engineering Alberta Ltd. The authors would like to thank the Centre for Health Genomics and Informatics in the Cumming School of Medicine, University of Calgary for their assistance in the microbial analysis.

Conflicts of Interest: Hereby, the authors declare that the content of this article is subject to no conflict of interest.

\section{Abbreviations}

$\begin{array}{ll}\text { AS } & \text { Activated sludge } \\ \text { AGS } & \text { Aerobic granular sludge } \\ \text { BNR } & \text { Biological nutrient removal } \\ \text { N } & \text { Nitrogen } \\ \text { P } & \text { Phosphorus } \\ \text { AN } & \text { Autotrophic nitrification } \\ \text { AXD } & \text { Anoxic denitrification } \\ \text { PAOs } & \text { Polyphosphate accumulating organisms } \\ \text { HN } & \text { Heterotrophic nitrification } \\ \text { Anammox } & \text { Anaerobic ammonium oxidation } \\ \text { AD } & \text { Aerobic denitrification } \\ \text { SND } & \text { Simultaneous nitrification-denitrification } \\ \text { PHAs } & \text { Polyhydroxyalkanoates } \\ \text { Poly-P } & \text { Polyphosphate } \\ \text { Ortho-P } & \text { Orthophosphate } \\ \text { EBPR } & \text { Enhanced biological phosphate removal } \\ \text { DO } & \text { Dissolved oxygen } \\ \text { AN/O/AX/O_SBR } & \text { Alternating anaerobic/aerobic/anoxic/aerobic granular sequencing } \\ & \text { batch reactor } \\ \text { GSBR } & \text { Granular sequencing batch reactor } \\ \text { SBR } & \text { Sequencing batch reactor } \\ \text { O_SBR } & \text { purely aerobic granular sequencing batch reactors } \\ \text { HN_AS } & \text { Heterotrophic nitrification activated sludge reactor } \\ \text { AN_AS } & \text { Autotrophic nitrification activated sludge reactor } \\ \text { AN/O_AS } & \text { Alternating anaerobic/aerobic activated sludge reactor } \\ \text { ExAN_AS } & \text { Extended anaerobic activated sludge reactor } \\ \text { COD } & \text { Chemical oxygen demand } \\ \text { TOC } & \text { Total organic carbon } \\ \text { TN } & \text { Total nitrogen } \\ \text { C/N } & \text { Carbon to nitrogen } \\ \text { MLSS } & \text { Mixed liquor suspended solids } \\ & \end{array}$




\section{References}

1. Zhao, Y.; Huang, J.; Zhao, H.; Yang, H. Microbial community and N removal of aerobic granular sludge at high COD and N loading rates. Bioresour. Technol. 2013, 143, 439-446. [CrossRef]

2. Limpiyakorn, T.; Sonthiphand, P.; Rongsayamanont, C.; Polprasert, C. Abundance of amoA genes of ammonia-oxidizing archaea and bacteria in activated sludge of full-scale wastewater treatment plants. Bioresour. Technol. 2011, 102, 3694-3701. [CrossRef]

3. He, T.; Xie, D.; Li, Z.; Ni, J.; Sun, Q. Ammonium stimulates nitrate reduction during simultaneous nitrification and denitrification process by Arthrobacter arilaitensis Y-10. Bioresour. Technol. 2017, 239, 66-73. [CrossRef] [PubMed]

4. Su, J.; Zhang, K.; Huang, T.; Wen, G.; Guo, L.; Yang, S. Heterotrophic nitrification and aerobic denitrification at low nutrient conditions by a newly isolated bacterium, Acinetobacter sp. SYF26. Microbiology 2015, 161, 829-837. [CrossRef]

5. Ren, Y.X.; Yang, L.; Liang, X. The characteristics of a novel heterotrophic nitrifying and aerobic denitrifying bacterium, Acinetobacter junii YB. Bioresour. Technol. 2014, 171, 1-9. [CrossRef]

6. He, T.; Li, Z.; Sun, Q.; Xu, Y.; Ye, Q. Heterotrophic nitrification and aerobic denitrification by Pseudomonas tolaasii Y-11 without nitrite accumulation during nitrogen conversion. Bioresour. Technol. 2016, 200, 493-499. [CrossRef] [PubMed]

7. Li, C.; Yang, J.; Wang, X.; Wang, E.; Li, B.; He, R.; Yuan, H. Removal of nitrogen by heterotrophic nitrification-aerobic denitrification of a phosphate accumulating bacterium Pseudomonas stutzeri YG-24. Bioresour. Technol. 2015, 182, 18-25. [CrossRef]

8. Zhao, B.; An, Q.; He, Y.L.; Guo, J.S. N2O and N2 production during heterotrophic nitrification by Alcaligenes faecalis strain NR. Bioresour. Technol. 2012, 116, 379-385. [CrossRef]

9. Yang, X.P.; Wang, S.M.; Zhang, D.W.; Zhou, L.X. Isolation and nitrogen removal characteristics of an aerobic heterotrophic nitrifying-denitrifying bacterium, Bacillus subtilis A1. Bioresour. Technol. 2011, 102, 854-862. [CrossRef] [PubMed]

10. Huang, F.; Pan, L.; Lv, N.; Tang, X. Characterization of novel Bacillus strain N31 from mariculture water capable of halophilic heterotrophic nitrification-aerobic denitrification. J. Biosci. Bioeng. 2017, 124, 564-571. [CrossRef]

11. Su, J.J.; Liu, B.Y.; Liu, C.Y. Comparison of aerobic denitrification under high oxygen atmosphere by Thiosphaera pantotropha ATCC 35512 and Pseudomonas stutzeri SU2 newly isolated from the activated sludge of a piggery wastewater treatment system. J. Appl. Microbiol. 2001, 90, 457-462. [CrossRef] [PubMed]

12. Cui, M.; Chen, F.; Fu, J.; Sheng, G.; Sun, G. Microbial metabolism of quinoline by Comamonas sp. World J. Microbiol. Biotechnol. 2004, 20, 539-543. [CrossRef]

13. de Kreuk, M.K.; Heijnen, J.J.; van Loosdrecht, M.C.M. Simultaneous COD, nitrogen, and phosphate removal by aerobic granular sludge. Biotechnol. Bioeng. 2005, 90, 761-769. [CrossRef] [PubMed]

14. Wei, Y.; Ji, M.; Li, R.; Qin, F. Organic and nitrogen removal from landfill leachate in aerobic granular sludge sequencing batch reactors. Waste Manag. 2012, 32, 448-455. [CrossRef]

15. Zhang, S.; Sun, X.; Fan, Y.; Qiu, T.; Gao, M.; Wang, X. Heterotrophic nitrification and aerobic denitrification by Diaphorobacter polyhydroxybutyrativorans SL-205 using poly(3-hydroxybutyrate-co-3-hydroxyvalerate) as the sole carbon source. Bioresour. Technol. 2017, 241, 500-507. [CrossRef]

16. Mino, T.; van Loosdrecht, M.C.M.; Heijnen, J.J. Microbiology and biochemistry of the enhanced biological phosphate removal process. Water Res. 1998, 32, 3193-3207. [CrossRef]

17. Pijuan, M.; Guisasola, A.; Baeza, J.A.; Carrera, J.; Casas, C.; Lafuente, J. Aerobic phosphorus release linked to acetate uptake: Influence of PAO intracellular storage compounds. Biochem. Eng. J. 2005, 26, 184-190. [CrossRef]

18. Guisasola, A.; Pijuan, M.; Baeza, J.A.; Carrera, J.; Casas, C.; Lafuente, J. Aerobic phosphorus release linked to acetate uptake in bio-P sludge: Process modeling using oxygen uptake rate. Biotechnol. Bioeng. 2004, 85, 722-733. [CrossRef] [PubMed]

19. Oehmen, A.; Lemos, P.C.; Carvalho, G.; Yuan, Z.; Keller, J.; Blackall, L.L.; Reis, M.A.M. Advances in enhanced biological phosphorus removal: From micro to macro scale. Water Res. 2007, 41, 2271-2300. [CrossRef]

20. Nguyen, H.T.T.; Le, V.Q.; Hansen, A.A.; Nielsen, J.L.; Nielsen, P.H. High diversity and abundance of putative polyphosphateaccumulating Tetrasphaera-related bacteria in activated sludge systems. FEMS Microbiol. Ecol. 2011, 76, 256-267. [CrossRef]

21. Tarayre, C.; Charlier, R.; Delepierre, A.; Brognaux, A.; Bauwens, J.; Francis, F.; Dermience, M.; Lognay, G.; Taminiau, B.; Daube, G.; et al. Looking for phosphate-accumulating bacteria in activated sludge processes: A multidisciplinary approach. Environ. Sci. Pollut. Res. 2017, 24, 8017-8032. [CrossRef] [PubMed]

22. Kong, Y.; Xia, Y.; Nielsen, J.L.; Nielsen, P.H. Ecophysiology of a group of uncultured Gammaproteobacterial glycogenaccumulating organisms in full-scale enhanced biological phosphorus removal wastewater treatment plants. Environ. Microbiol. 2006, 8, 479-489. [CrossRef]

23. Ferrera, I.; Sánchez, O. Insights into microbial diversity in wastewater treatment systems: How far have we come? Biotechnol. Adv. 2016, 34, 790-802. [CrossRef]

24. Han, Y.-H.; Fu, T.; Wang, S.-S.; Yu, H.-T.; Xiang, P.; Zhang, W.-X.; Chen, D.-L.; Li, M. Efficient phosphate accumulation in the newly isolated Acinetobacter junii strain LH4. 3 Biotech 2018, 8, 1-12. [CrossRef]

25. Pishgar, R.; Hamza, R.A.; Tay, J.H. Augmenting Lagoon Process Using Reactivated Freeze-dried Biogranules. Appl. Biochem. Biotechnol. 2017, 183, 137-154. [CrossRef] [PubMed]

26. Pishgar, R.; Dominic, J.A.; Sheng, Z.; Tay, J.H. Denitrification performance and microbial versatility in response to different selection pressures. Bioresour. Technol. 2019, 281, 72-83. [CrossRef]

27. Pishgar, R.; Dominic, J.A.; Sheng, Z.; Tay, J.H. Influence of operation mode and wastewater strength on aerobic granulation at pilot scale: Startup period, granular sludge characteristics, and effluent quality. Water Res. 2019, 160, 81-96. [CrossRef] 
28. Pishgar, R.; Dominic, J.A.; Tay, J.H.; Chu, A. Pilot-scale investigation on nutrient removal characteristics of mineral-rich aerobic granular sludge: Identification of uncommon mechanisms. Water Res. 2019, 168, 115151. [CrossRef] [PubMed]

29. Pishgar, R.; Kanda, A.; Gress, G.R.; Gong, H.; Dominic, J.A.; Tay, J.H. Effect of aeration pattern and gas distribution during scale-up of bubble column reactor for aerobic granulation. J. Environ. Chem. Eng. 2018, 6, 6431-6443. [CrossRef]

30. Pishgar, R. Nutrient Removal (Ammonium and Phosphate) Using Aerobic Granulation at Pilot Scale. Ph.D. Thesis, University of Calgary, Calgary, AB, Canada, 2019.

31. Kim, M.; Jeong, S.-Y.; Yoon, S.J.; Cho, S.J.; Kim, Y.H.; Kim, M.J.; Ryu, E.Y.; Lee, S.-J. Aerobic Denitrification of Pseudomonas putida AD-21 at Different C/N Ratios. J. Biosci. Bioeng. 2008, 106, 498-502. [CrossRef]

32. Joong, K.K.; Kyoung, J.P.; Kyoung, S.C.; Nam, S.W.; Park, T.J.; Bajpai, R. Aerobic nitrification-denitrification by heterotrophic Bacillus strains. Bioresour. Technol. 2005, 96, 1897-1906. [CrossRef]

33. Joo, H.-S.; Hirai, M.; Shoda, M. Characteristics of ammonium removal by heterotrophic nitrification-aerobic denitrification by Alcaligenes faecalis No. 4. J. Biosci. Bioeng. 2005, 100, 184-191. [CrossRef]

34. van Niel, E.W.J.; Arts, P.A.M.; Wesselink, B.J.; Robertson, L.A.; Kuenen, J.G. Competition between heterotrophic and autotrophic nitrifiers for ammonia in chemostat cultures. FEMS Microbiol. Lett. 1993, 102, 109-118. [CrossRef]

35. Castignetti, D.; Hollocher, T.C. Heterotrophic nitrification among denitrifiers. Appl. Environ. Microbiol. 1984, 47, 620-623. [CrossRef]

36. Castignetti, D.; Forgue, C.J.; Sclafan, L.A. Pathway of Oxidation of Pyruvic Oxime by a Heterotrophic Nitrifier of the Genus Alcaligenes: Evidence against Nitroethane as an Intermediate. Arch. Biochem. Biophys. 1986, 250, 228-232. [CrossRef]

37. Eylar, O.R.; Schmidt, E.L. A survey of heterotrophic micro-organisms from soil for ability to form nitrite and nitrate. J. Gen. Microbiol. 1959, 20, 473-481. [CrossRef] [PubMed]

38. Wrage, N.; Velthof, G.L.; Van Beusichem, M.L.; Oenema, O. Role of nitrifier denitrification in the production of nitrous oxide. Soil Biol. Biochem. 2001, 33, 1723-1732. [CrossRef]

39. Zhang, J.; Sun, W.; Zhong, W.; Cai, Z. The substrate is an important factor in controlling the significance of heterotrophic nitrification in acidic forest soils. Soil Biol. Biochem. 2014, 76, 143-148. [CrossRef]

40. American Public Health Association (APHA); American Water Works Association (AWWA); Water Environment Federation (WEF). Standard Methods for the Examination of Water and Wastewater, 22nd ed.; American Public Health Association: Washington, DC, USA, 2012.

41. Zhang, J.; Wu, P.; Hao, B.; Yu, Z. Heterotrophic nitrification and aerobic denitrification by the bacterium Pseudomonas stutzeri YZN-001. Bioresour. Technol. 2011, 102, 9866-9869. [CrossRef]

42. Sun, Y.; Feng, L.; Li, A.; Zhang, X.; Yang, J.; Ma, F. Ammonium assimilation: An important accessory during aerobic denitrification of Pseudomonas stutzeri T13. Bioresour. Technol. 2017, 234, 264-272. [CrossRef] [PubMed]

43. Joo, H.S.; Hirai, M.; Shoda, M. Piggery wastewater treatment using Alcaligenes faecalis strain No. 4 with heterotrophic nitrification and aerobic denitrification. Water Res. 2006, 40, 3029-3036. [CrossRef] [PubMed]

44. Moir, J.W.B.; Wehrfritz, J.; Spiro, S.; Richardson, D.J. The biochemical characterization of a nover non-haem-iron hydroxylamine oxidase from Paracococcus denitrifiecans GB17. Biochem. J. 1996, 319, 823-827. [CrossRef] [PubMed]

45. Gonzalez-Gil, G.; Holliger, C. Dynamics of microbial community structure of and enhanced biological phosphorus removal by aerobic granules cultivated on propionate or acetate. Appl. Environ. Microbiol. 2011, 77, 8041-8051. [CrossRef]

46. Bin, Z.; Ji, M.; Qiu, Z.; Liu, H.; Wang, J.; Li, J. Microbial population dynamics during sludge granulation in an anaerobic-aerobic biological phosphorus removal system. Bioresour. Technol. 2011, 102, 2474-2480. [CrossRef]

47. Liu, B.; Zhang, F.; Feng, X.; Liu, Y.; Yan, X.; Zhang, X.; Wang, L.; Zhao, L. Thauera and Azoarcus as functionally important genera in a denitrifying quinoline-removal bioreactor as revealed by microbial community structure comparison. FEMS Microbiol. Ecol. 2006, 55, 274-286. [CrossRef]

48. Liang, S.C.; Zhao, M.; Lu, L.; Wang, C.L.; Zhao, L.Y.; Liu, W.J. Isolation and characteristic of an aerobic denitrifier with high nitrogen removal efficiency. Afr. J. Biotechnol. 2011, 10, 10648-10656. [CrossRef]

49. Strand, S.E.; McDonnell, A.J.; Unz, R.F. Oxygen and nitrate reduction kinetics of a nonflocculating strain of Zoogloea ramigera. Antonie Van Leeuwenhoek 1988, 255, 245-255. [CrossRef] [PubMed]

50. Huang, T.L.; Zhou, S.L.; Zhang, H.H.; Bai, S.Y.; He, X.X.; Yang, X. Nitrogen removal characteristics of a newly isolated indigenous aerobic denitrifier from oligotrophic drinking water reservoir, Zoogloea sp. N299. Int. J. Mol. Sci. 2015, 16, 10038-10060. [CrossRef]

51. Nielsen, P.H.; Mielczarek, A.T.; Kragelund, C.; Nielsen, J.L.; Saunders, A.M.; Kong, Y.; Hansen, A.A.; Vollertsen, J. A conceptual ecosystem model of microbial communities in enhanced biological phosphorus removal plants. Water Res. 2010, 44, 5070-5088. [CrossRef]

52. Wells, G.F.; Park, H.D.; Yeung, C.H.; Eggleston, B.; Francis, C.A.; Criddle, C.S. Ammonia-oxidizing communities in a highly aerated full-scale activated sludge bioreactor: Betaproteobacterial dynamics and low relative abundance of Crenarchaea. Environ. Microbiol. 2009, 11, 2310-2328. [CrossRef]

53. Berg, P.E.R.; Klemedtssn, L.; Rosswall, T. Inhibitory effect of low partial pressures of acetylene on nitrification. Soil Biol. Biochem. 1982, 14, 301-303. [CrossRef]

54. Aravind, J.; Saranya, T.; Kanmani, P. Optimizing the production of Polyphosphate from Acinetobacter towneri. Glob. J. Environ. Sci. Manag. 2015, 1, 63-70. [CrossRef] 
55. Kong, Y.; Xia, Y.; Nielsen, J.L.; Nielsen, P.H. Structure and function of the microbial community in a full-scale enhanced biological phosphorus removal plant. Microbiology 2007, 153, 4061-4073. [CrossRef]

56. Kim, J.M.; Lee, H.J.; Lee, D.S.; Jeon, C.O. Characterization of the denitrification-associated phosphorus uptake properties of "Candidatus Accumulibacter phosphatis" clades in sludge subjected to enhanced biological phosphorus removal. Appl. Environ. Microbiol. 2013, 79, 1969-1979. [CrossRef] [PubMed]

57. Coats, E.R.; Brinkman, C.K.; Lee, S. Characterizing and contrasting the microbial ecology of laboratory and full-scale EBPR systems cultured on synthetic and real wastewaters. Water Res. 2017, 108, 124-136. [CrossRef] [PubMed]

58. Ahn, J.; Schroeder, S.; Beer, M.; McIlroy, S.; Bayly, R.C.; May, J.W.; Vasiliadis, G.; Seviour, R.J. Ecology of the microbial community removing phosphate from wastewater under continuously aerobic conditions in a sequencing batch reactor. Appl. Environ. Microbiol. 2007, 73, 2257-2270. [CrossRef]

59. Horn, M.A.; Ihssen, J.; Matthies, C.; Schramm, A.; Acker, G.; Drake, H.L. Dechloromonas denitrificans sp. nov., Flavobacterium denitrificans sp. nov., Paenibacillus anaericanus sp. nov. and Paenibacillus terrae strain MH72, N2O-producing bacteria isolated from the gut of the earthworm Aporrectodea caliginosa. Int. J. Syst. Evol. Microbiol. 2005, 55, 1255-1265. [CrossRef]

60. Yilmaz, G.; Lemaire, R.; Keller, J.; Yuan, Z. Simultaneous nitrification, denitrification, and phosphorus removal from nutrient-rich industrial wastewater using granular sludge. Biotechnol. Bioeng. 2008, 100, 529-541. [CrossRef] [PubMed]

61. Bassin, J.P.; Kleerebezem, R.; Dezotti, M.; van Loosdrecht, M.C.M. Simultaneous nitrogen and phosphate removal in aerobic granular sludge reactors operated at different temperatures. Water Res. 2012, 46, 3805-3816. [CrossRef]

62. Wang, J.; Qi, R.; Liu, M.; Li, Q.; Bao, H.; Li, Y.; Wang, S.; Tandoi, V.; Yang, M. The potential role of "Candidatus Microthrix parvicella" in phosphorus removal during sludge bulking in two full-scale enhanced biological phosphorus removal plants. Water Sci. Technol. 2014, 70, 367-375. [CrossRef]

63. McIlroy, S.J.; Kristiansen, R.; Albertsen, M.; Karst, S.M.; Rossetti, S.; Nielsen, J.L.; Tandoi, V.; Seviour, R.J.; Nielsen, P.H. Metabolic model for the filamentous "Candidatus Microthrix parvicella" based on genomic and metagenomic analyses. ISME J. 2013, 7, 1161-1172. [CrossRef] [PubMed]

64. Rashid, M.H.; Rumbaugh, K.; Passador, L.; Davies, D.G.; Hamood, A.N.; Iglewski, B.H.; Kornberg, A. Polyphosphate kinase is essential for biofilm development, quorum sensing, and virulence of Pseudomonas aeruginosa. Proc. Natl. Acad. Sci. USA 2000, 97, 9636-9641. [CrossRef]

65. Rashid, M.H.; Kornberg, A. Inorganic polyphosphate is needed for swimming, swarming, and twitching motilities of Pseudomonas aeruginosa. Proc. Natl. Acad. Sci. USA 2002, 97, 4885-4890. [CrossRef]

66. Kundu, P.; Pramanik, A.; Dasgupta, A.; Mukherjee, S.; Mukherjee, J. Simultaneous heterotrophic nitrification and aerobic denitrification by Chryseobacterium sp. R31 isolated from abattoir wastewater. Biomed. Res. Int. 2014, 2014, 436056. [CrossRef] [PubMed]

67. Patureau, D.; Davison, J.; Bernet, N.; Moletta, R. Dentrification under various aeration conditions in Comomonas sp., strain SGLY2. FEMS Microbiol. Lett. 1994, 14, 71-78. [CrossRef]

68. Wan, C.; Lee, D.-J.; Yang, X.; Wang, Y.; Wang, X.; Liu, X. Calcium precipitate induced aerobic granulation. Bioresour. Technol. 2015, 176, 32-37. [CrossRef]

69. Wan, C.; Zhang, P.; Lee, D.J.; Yang, X.; Liu, X.; Sun, S.; Pan, X. Disintegration of aerobic granules: Role of second messenger cyclic di-GMP. Bioresour. Technol. 2013, 146, 330-335. [CrossRef]

70. Adav, S.S.; Lee, D.J.; Lai, J.Y. Potential cause of aerobic granular sludge breakdown at high organic loading rates. Appl. Microbiol. Biotechnol. 2010, 85, 1601-1610. [CrossRef] [PubMed] 